\title{
MOOC in the West and East: A Comparative Content Analysis of Newspapers
}

\section{(MOOC en Occidente y Oriente: Un análisis de contenido comparativo en los periódicos)}

\author{
Jingshan Liu \\ Universidad Carlos III de Madrid (Spain)
}

DOI: https://doi.org/10.5944/ried.24.2.29290

\section{How to reference this article:}

Liu, J. (2021). MOOC in the West and East: A Comparative Content Analysis of Newspapers. RIED. Revista Iberoamericana de Educación a Distancia, 24(2), pp. 309-327. https://doi.org/10.5944/ried.24.2.29290

\begin{abstract}
One of the most notable differences between massive open online courses (MOOCs) and other educational technology innovations is the general public's unprecedented interest and participation. This study presents a comparative analysis of MOOCs' public debate in different countries, focusing on media content in national newspapers related to MOOCs in China and Spain. The most critical themes in the main newspapers in both countries related to the MOOCs between 2012 and 2019 are identified. The analysis is made in 456 articles content, examining whether there is a different interpretation of different language and cultural backgrounds. The results indicate that the MOOC coverage has changed significantly over the eight years in both countries, with 2014 being the year with the most extensive regular publication on the MOOC topic in both countries. Since then, the total number of articles shows a clear downward trend in China, and Spanish newspapers started to reduce MOOC coverage, but it increases again from 2017 onwards. The focus of the MOOC discourse in the Chinese and Spanish newspapers is different from the English newspaper. In contrast, the articles in Spain focus on the possibility of using MOOCs in professional training and employment. In China, the focus seems to move towards educational equality regulations and educational policies in the 21st century.
\end{abstract}

Keywords: MOOC; China; Spain; newspaper.

\section{Resumen}

Una de las diferencias más llamativa entre los cursos online masivo en abierto o MOOC y las innovaciones anteriores de la tecnología educativa es el interés y la participación sin 
precedentes del público en general. Este estudio presenta un análisis comparativo del debate público en torno a los MOOC en diferentes países, enfocándose los contenidos mediáticos en los periódicos nacionales relacionados con los MOOC en China y España. Se identifican los temas más importantes en los principales periódicos en ambos países relacionados con los MOOC entre los años 2012 y 2019, llevándose a cabo un análisis en 456 artículos sobre su contenido, examinando si existe una interpretación distinta desde el idioma y la cultura diferente. Los resultados indican que la cobertura de los MOOC ha cambiado significativamente en los ocho años en ambas naciones, siendo el año 2014 el año con la mayor publicación periódica sobre el tema de los MOOC en ambos países. Desde entonces, el número total de artículos muestra una clara tendencia descendente en China, y los periódicos españoles empezaron a reducir la cobertura de los MOOC, pero vuelve a aumentar a partir del año 2017. El enfoque del discurso MOOC en periódico chino y español es diferente al periódico inglés, mientras que los artículos en España se centran en la utilización de los MOOC en formación profesional y empleo, en China, el enfoque parece moverse hacia las regulaciones y las políticas en la Educación en Igualdad del siglo XXI.

Palabras clave: MOOC; China; España; periódico.

The MOOCs began to occur at a specific time and have hit the university education landscape. To date, educational institutions and universities in more than 60 countries offer courses through the leading providers Coursera, edX, or Futurelearn (MOOC List, 2020). Although the UNESCO (United Nations Educational, Scientific and Cultural Organization) and COL (Commonwealth of Learning) have established a guide on MOOCs to expand access to education worldwide at the digital age (UNESCO \& COL, 2016), worldwide education is still challenging considering the socio-cultural barriers. Indeed, different cultural and social backgrounds pose significant challenges for MOOC providers to access learners in different countries (Reich \& Ruipérez-Valiente, 2019). As MOOCs are open to learners through an online environment, thus a single course might have registered for thousands of learners from different regions at the same time. MOOC learners from different regions and country backgrounds show significant differences in their performance (Gameel \& Wilkins, 2019). A better understanding of the country differences in which the learners live can help MOOC educators make users succeed in their courses.

Furthermore, one of MOOCs' most disruptive aspects is the general public's unprecedented interest and participation. The current debate about MOOCs also has been widely discussed in mainstream media. Although social media are seen as a useful tool that could share public perception and improve cooperative learning between learners in the virtual space (Costello et al., 2018; Shao et al., 2020), public discussions through online platforms may be limited to a niche community of likeminded education technology practitioners and MOOC providers (Bulfin et al., 2014). As most of the general public is likely to encounter MOOC-related news in mainstream newspapers, the news sources of this kind of media seem to significantly 
influence online education's ongoing development as another educational form. In line with this perception, this paper aims to understand better how discursive strategies accompanying the emergence of media discourses will shape the MOOC adaptation and public understanding in different countries. The analysis also aims to improve the understanding of the MOOC users' social backgrounds in China and Spain.

This article is organized as follows. First, a literature review was conducted to discuss the main rhetorical and discursive patterns of the media content characterizing MOOC's emergence in newspapers. Second, the article discusses framing theory and transnational research design as a useful framework to compare different mainstream media discourses in different countries. After briefly describing MOOCs' current development in China and Spain, the most critical themes in the prominent newspapers in both countries related to the MOOCs are identified and compared between 2012 and 2019. In conclusion, the study contends that the discourses set in motion by MOOC represent a cultural difference in Chinese and Spanish newspapers that may influence and shape the current social imaginary and public perception of online education in their context.

\section{THEORETICAL FRAMEWORK}

\section{The media construction of MOOC discourses}

The MOOCs first captured media attention in 2012, while the same year was also defined as the year of MOOC by Pappano (2012) in The New York Times. Since then, educational innovation with technology topics has been widely discussed in the mainstream media coverages. Recently, many researchers have examined the representation of MOOCs in mainstream newspapers (Bulfin et al., 2014; Deimann, 2015; Kovanović et al., 2015; White et al., 2015; Brown et al., 2016; Kovanović et al., 2016; Dumitrica, 2017) (see Figure 1).

Among them, Bulfin et al. (2014) analyzed newspapers in Australia, the United Kingdom, and the United States. They found MOOCs' central theme is related to the massification, commercialization, and monetization of universities instead of talking about technological or educational advancement. After analyzing all the news articles published in the English language during 2013 and 2014, Kovanović et al. (2015) found that the dominant themes were finance, business, and investment. While the MOOC platform and the adaptation in the global arena such as India, China, the United States, and Australia also figured prominently. White et al. (2015) discovered that the most discussed topics in the major higher education journals were impacted by teaching, universities, and new business models. In more depth, Deimann (2015) compared the constructed discourses of MOOCs in the media and social reality by analyzing the news published in The New York Times (2012-2013). In another study that attempted to look at the relationship between higher education 
construction and MOOCs, Dumitrica (2017) used the method of critical discourse analysis to analyze print coverage in Canada on the topic of MOOCs.

Previous studies were concentered on the analysis of English languages newspaper. Their results showed that the most popular themes in the MOOCs' related discourse represented in mainstream media were based on the economic framework and neoliberal reform of higher education through technological innovation. On the other hand, little was known about the MOOC discussion in non-English language mainstream media such as Chinese and Spanish language newspapers. Even less is known about how different countries have portrayed, positioned, and discussed the MOOC topic during times.

\section{Figure 1}

Previous studies on media discourses of the MOOC topic

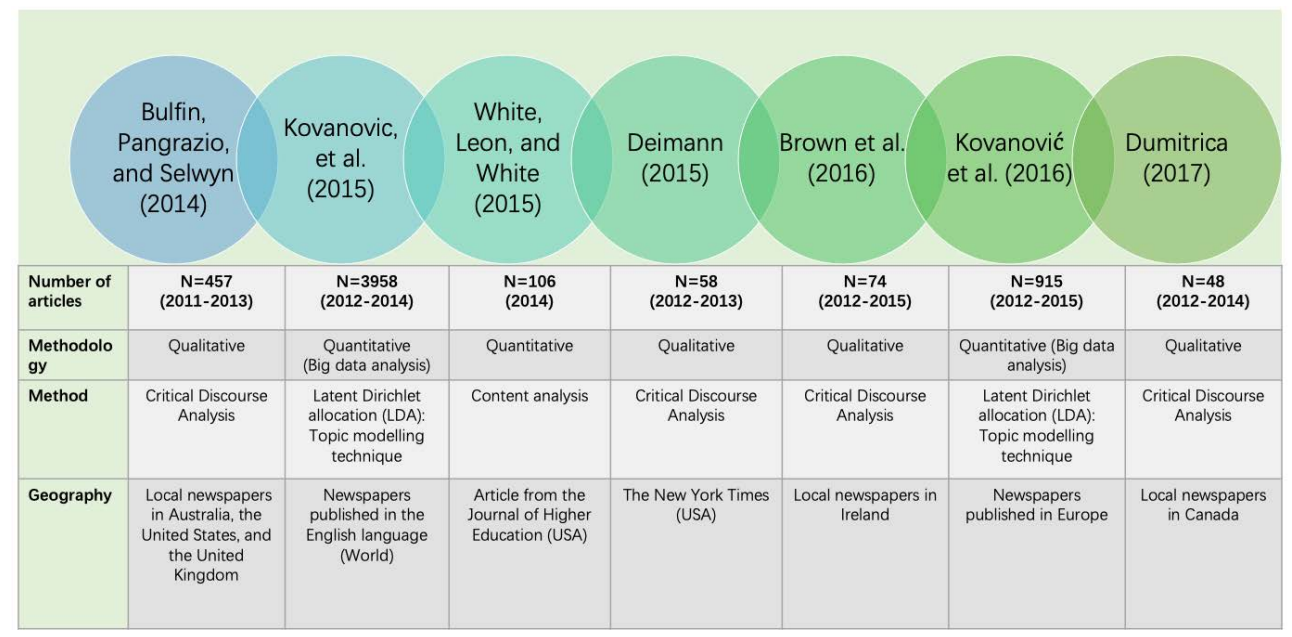

Source: own elaboration

\section{Framing theory and transnational research design}

The MOOCs have found a unique position in mainstream media coverage, which has increased the general public concerns and discussions of online learning. Framing theory suggests that the information presented to the audience may influence their form to process that information. In media content study, the framing theory was widely used to analyze how the media information is framed to influence the public perception of a social issue in the news. The work to process and organize media message meaning was considered as the media frames. As with most social issues such as education, MOOCs' public perception is likely influenced 
by media representation (McCombs \& Shaw, 1972; Rogers et al., 2005; Scheufele \& Tewksbury, 2007). The increasing use of transnational research design allows us to test the social system's influence on news discourses and unravel the institutional level frames (Benson, 2013). Van Dijk (2013) presented two alternative hypotheses on comparative studies in media contents, based on arguments drawn from the study of intercultural discourse and communication. Cultural, social, ideological, or political differences in different countries may influence the discourses' presentation on a given topic. Otherwise, based on globalization's influence, media discourses do not reflect differences, and their news production derives from the international cultural monopoly and shows similarity in representation. The comparison of public debates in the mainstream media may provide helpful hints for understanding MOOC development during eight years in the Western and Eastern countries and how the online educational environment is constructed differently.

\section{MOOC in China and Spain}

In China, MOOCs have become one of the most relevant issues in China's educational field since 2015 (Zhang et al., 2015). As the Ministry of Education China aims to improve their quality of current higher education and promote Chinese universities' reputation globally, MOOCs have become an essential national educational policy in China (Zheng \& Yang, 2017, Zhang et al., 2019). According to the report in the first Global MOOC conference co-hold by Tsinghua University and UNESCO, over 30 MOOC platforms had offered more than 34,000 courses in which more than 540 million users had registered in China. By October of 2020, China ranks first globally in online courses and users (Zou, 2020). As indicated by the study of Shang and Cao (2017), the development of digital higher education is at a prominent stage in China. As the national policy support is significantly enhanced and capital investment increased, the Chinese educational system will leave an enormous development in the digital space in the future.

In Spain, UNED was the first Higher Education institution to offer MOOC courses on the UNED COMA platform in October 2012. Miríadax (www.miriadax. net) is the first non-English speaking platform globally, with more than 7 million enrollments and 100 educational partners. It was considered the most widely used platform by universities in Spain and Latina America (Medina-Salguero \& Aguaded, 2014; Zapata-Ros, 2015; Navarro \& Barreto, 2018). According to the data provided by Cano and Meneses (2014), Spain was the leading provider of MOOCs in the European framework, being one of the most active countries in the world since 2015. As digital education has been confirmed as one of the most relevant priorities of the European Commission (European Commission, 2018), the Spanish university community's MOOC offer is continuously growing (García-Peñalvo et al., 2018). A recent survey conducted by Aguado (2020) has suggested that Spanish students valued very positively in digital education tools and almost unanimously preferred 
the combination pattern of MOOCs and face-to-face teaching as an ideal form of learning.

MOOCs are a relevant issue in Chinese and Spanish society, and newspapers will likely involve the MOOC issue and support the media discourses. The study towards local newspapers in other languages from different social and cultural contexts is lacking. Comparing the social debates and public discourses in China and Spain, content analysis (Neuendorf, 2017) has been carried out on both countries' general and educational newspapers during the years 2012 and 2019. Considering many potential MOOC users are native Chinese and Spanish speakers, this paper presents an interesting comparative study in this context to find out how MOOCs have been represented to their local audience in Chinese and Spanish society. In this sense, this research has the following questions:

1. How has the number of newspaper articles in the MOOCs' media coverage changed over time between the two countries (2012-2019)?

2. What are the dominant themes in one country and another?

3. Are there any differences or similarities between the MOOC themes presentation in Chinese and Spanish newspapers?

\section{METHODOLOGY}

Analyzing MOOC news coverage in Chinese and Spanish newspapers, the research was conducted by searching independently articles related to the MOOCs in both the Chinese and Spanish press through the Spanish (Mynews) and Chinese (China Core Newspapers Full-text Database) databases. Mynews has been a digital archive of the Spanish press since 1996, which includes almost 200 press titles, while the China Core Newspapers Full-text Database includes more than 500 titles from the Chinese press from 2000 onwards. The period of publications between January 2012 and September 2019 has been selected, considered a complete MOOC debate period globally. In this sense, six general newspapers in Spain (ABC, El País, and El Mundo) and China (The People's Daily, Guang Ming Daily, and China Youth Daily) have been selected. As well as two newspapers specialized in education, Magisnet from Spain and China Education Newspaper from China. In order to identify the articles, the search uses the English abbreviation "MOOC" or "Massive online open courses," the Spanish "CEMA" or "Curso En-línea Masivo y Abierto" and the Chinese “慕课” through Mynews and China Core Newspapers Full-text Database. After removing duplicate articles, articles that are not predominantly focused on the MOOC topic are manually excluded. Initially, 485 articles were identified, including 456 articles that met the inclusion criteria and were eligible for the coding and analysis process.

In order to codify and analyze media content, the quantitative methodology of content analysis is applied. In the first phase, quantitative analysis was used to measure article frequencies across the sample. In the second phase, a more in-depth 
content analysis was carried out to compare MOOC themes. A thematic analysis illustrates the main topics or ideas of a news article. In this sense, the coding process was close to a qualitative approach. Finally, the quantitative analysis focuses on measuring and analyzing the contents with the data collected. The methods of this research consist of the following steps:

1. Build a coding framework.

2. Codify the article contents using the coding framework.

3. Establish the reliability of the data collected and exclude unreliable data.

4. Analyze quantitative data.

5. Carry out a comparative analysis derived from the data.

In constructing a coding framework to encode the content, a search for the most frequent words in all the samples in group 1 (Chinese newspapers) and group 2 (Spanish newspapers) was conducted. Two coders read the randomly selected subsamples in an SPSS program of 50 articles representing $10.7 \%$ in all the samples (28 in Spanish newspapers and 22 in Chinese newspapers), identifying the most relevant topics related to the research. When the coders do not find any new categories, the list of categories is saturated. In this sense, the collected topics were grouped into four categories: 1) Educational aspects, 2) MOOC infrastructure aspects, 3) Social aspects 4) Other aspects. The coding framework format contains four categories of topics and their subcategories while also collecting detailed information on the articles, such as the year of publication and edition. Besides, each coder collects information in two categories per country. The results allow analyzing if the themes vary according to their different cultural context.

To collect the quantitative data, coder A reads each article, in turn, using the coding framework to examine whether the themes are represented in the contents of the articles. To ensure the coding process's consistency and reliability, coder B codes a random subsample of 59 articles representing $12.6 \%$ of the sample, including 35 articles from Spain representing 12.8\% in Spanish newspapers and 24 articles from China representing $12.2 \%$ in Chinese newspapers. The Kappa coefficient $(\kappa)$ is used to examine the intercoder's reliability in each variable across the 59 double-coded items. The variables must obtain values greater than 0.80 to enter the next analysis process only retains the strongly agreed variables. After examining reliability, only 14 variables met our criteria for inclusion (see table 1). All data collected are calculated through the SPSS program. The statistical procedures are a simple linear regression that examines the relationship between the number of articles published and the year of publication in China and Spain and the Chi-squared test $\left(\chi_{2}\right)$ to examine whether thematic variables vary in both countries. A condition for the appropriate use of the test $\chi^{2}$ was that each expected frequency is at least 5 . After computing all the expected frequencies of each variable, this is true for this sample (the smallest expected frequency is 21.9), and therefore it is appropriate to use the test statistic. 
The level of statistical significance is set at 0.01 to reduce the probability of a type I error.

\section{Table 1}

Categories of prominent topics and definition of variables

\begin{tabular}{|c|c|}
\hline Themes & Description \\
\hline \multicolumn{2}{|l|}{ Educational aspects } \\
\hline $\begin{array}{l}\text { 1.Universities and Higher } \\
\text { Education }\end{array}$ & $\begin{array}{l}\text { Any application and integration of MOOCs in } \\
\text { universities; competition between universities. }\end{array}$ \\
\hline $\begin{array}{l}\text { 2. Primary and Secondary } \\
\text { Education }\end{array}$ & $\begin{array}{l}\text { Any application and integration of MOOCs in Primary } \\
\text { and Secondary Education. }\end{array}$ \\
\hline 3. Pedagogy & MOOCs' teaching models and instructional design. \\
\hline 4.Students and Learners & $\begin{array}{l}\text { Individual taking MOOC as learners; learning } \\
\text { experiences. }\end{array}$ \\
\hline 5.Teachers & $\begin{array}{l}\text { Teacher and other teaching staff within MOOCs; } \\
\text { teaching experiences. }\end{array}$ \\
\hline $\begin{array}{l}\text { 6.Global and International } \\
\text { Education }\end{array}$ & MOOCs are described as a worldwide phenomenon. \\
\hline $\begin{array}{l}\text { 7.Educational equity and } \\
\text { equality }\end{array}$ & $\begin{array}{l}\text { MOOCs are described as a useful tool for promoting } \\
\text { educational equity and equality in the digital age. }\end{array}$ \\
\hline \multicolumn{2}{|l|}{ MOOC Infrastructure aspects } \\
\hline 8. Platform & $\begin{array}{l}\text { Cooperation of international MOOC platforms such as } \\
\text { Coursera, edX..etc; Construction of national MOOC } \\
\text { platforms. }\end{array}$ \\
\hline $\begin{array}{l}\text { 9.MOOC credentials and } \\
\text { certificates }\end{array}$ & $\begin{array}{l}\text { Credentialization of degree; acquisition of certification; } \\
\text { assessment of student work. }\end{array}$ \\
\hline \multicolumn{2}{|l|}{ Social aspects } \\
\hline 10.MOOCs and enterprise & Enterprise cooperation in MOOC development. \\
\hline 11.MOOCs and government & $\begin{array}{l}\text { Government support in MOOC development; } \\
\text { educational policy of MOOCs. }\end{array}$ \\
\hline 12.MOOCs and employability & $\begin{array}{l}\text { Vocational training through MOOCs; enhancement of } \\
\text { employability. }\end{array}$ \\
\hline 13.Business and economic & $\begin{array}{l}\text { Scale of investment; emerging business models; } \\
\text { method of monetization and profit making. }\end{array}$ \\
\hline \multicolumn{2}{|l|}{ Other aspects } \\
\hline 14. The problem with MOOCs & $\begin{array}{l}\text { Barriers to the development of MOOCs; high dropout } \\
\text { rates of students; other problems and negative aspects } \\
\text { of MOOCs. }\end{array}$ \\
\hline
\end{tabular}

Source: own elaboration 


\section{RESULTS}

Table 2

Publication and articles in the sample

\begin{tabular}{|l|l|r|r|}
\hline \multirow{2}{*}{ Country } & \multicolumn{1}{|c|}{ Publication } & \multicolumn{1}{|c|}{$\begin{array}{c}\text { Number of } \\
\text { articles }\end{array}$} & Percentage \\
\hline \multirow{2}{*}{$\begin{array}{l}\text { Spain } \\
(n=260)\end{array}$} & ABC & 36 & $7.9 \%$ \\
\cline { 2 - 4 } & El Mundo & 163 & $35.7 \%$ \\
\cline { 2 - 4 } & El País & 58 & $12.7 \%$ \\
\cline { 2 - 4 } & Magisnet & 3 & $0.7 \%$ \\
\cline { 2 - 4 } & China Education Newspaper & 78 & $17.1 \%$ \\
\cline { 2 - 4 } & The People's Daily & 40 & $8.8 \%$ \\
\cline { 2 - 4 } & Guang Ming Daily & 45 & $9.9 \%$ \\
\cline { 2 - 4 }$\left(\begin{array}{l}\text { China } \\
(n=196)\end{array}\right.$ & China Youth Daily & 33 & $7.2 \%$ \\
\cline { 2 - 4 } & Total & 456 & $100 \%$ \\
\hline
\end{tabular}

Source: own elaboration

\section{Figure 2}

Publication numbers per press

Number of published articles

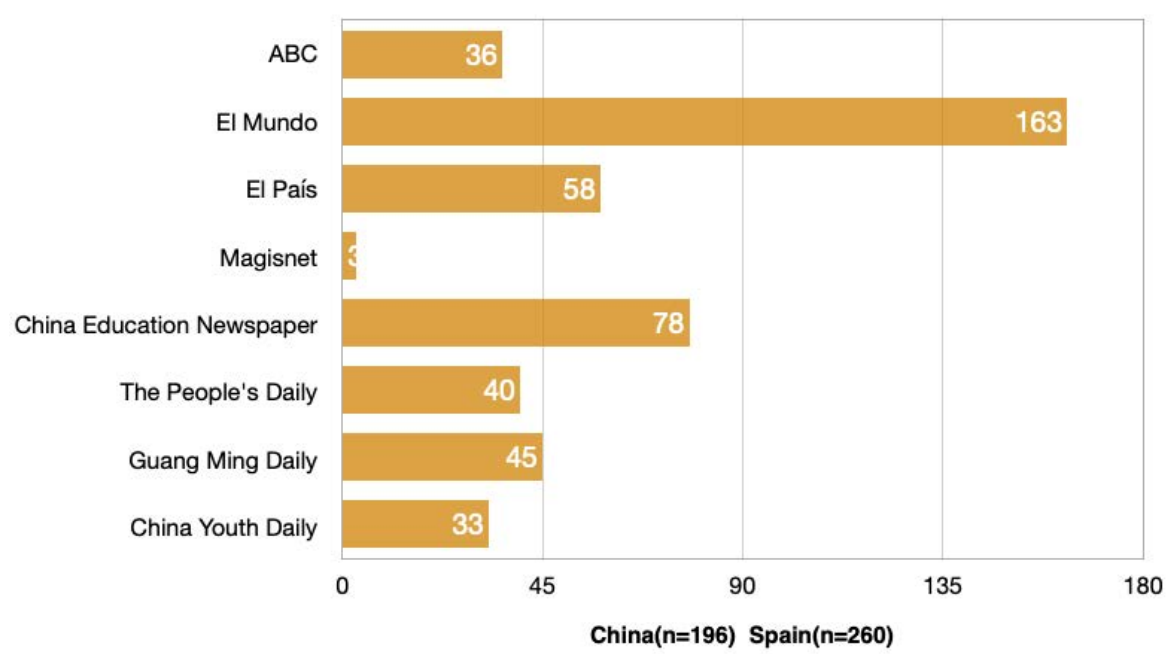

Source: own elaboration 
Between January 2012 and September 2019, the 456 articles on the MOOC topic were published in six major newspapers and two specialist education periods in China and Spain. Among the articles published, 260 were found in Spanish newspapers and 196 Chinese newspapers (see Table 2 and Figure 2). Most of the Spanish articles published were in the generalized newspapers, these being $\mathrm{ABC}(\mathrm{n}=36,13.8 \%), \mathrm{El}$ Mundo ( $\mathrm{n}=163,62.7 \%)$, and El País $(\mathrm{n}=58,22.3 \%)$. However, limited articles were found in the specialized education newspaper Magisnet $(n=3,1.2 \%)$. On the other hand, Chinese newspaper articles related to the MOOC have been published mostly in the China Education Newspaper $(\mathrm{n}=78,39.8 \%$ ), while mainstream newspapers have the equivalent publication number represented by the People's daily $(n=40,20.4 \%)$, the Guang Ming Daily ( $\mathrm{n}=45,22.9 \%)$ and the China Youth Daily $(\mathrm{n}=33,16.8 \%)$. The results have compared the number of MOOC coverage has changed significantly over the eight years in both countries (see Figure 3), but the year of publication was not a statistically significant predictor of the frequency of articles in China (coefficient $-2,467, p=0,467$ ) or Spain (coefficient $0,393, p=0,898$ ). The year 2014 was the year with the largest number of periodicals on MOOCs in China $(n=53,27 \%)$ and Spain $(\mathrm{n}=58,21.2 \%)$. From 2016 onwards, Chinese newspapers started to reduce MOOC coverage, and only $23(11.7 \%)$ articles were found, while in Spain, after the fall in 2015, there was another peak in the publication of articles in $2017(n=56,20.5 \%)$, and then a clear downward trend in $2018(\mathrm{n}=20,7.3 \%)$.

\section{Figure 3}

Frequency of publication of MOOC articles per year

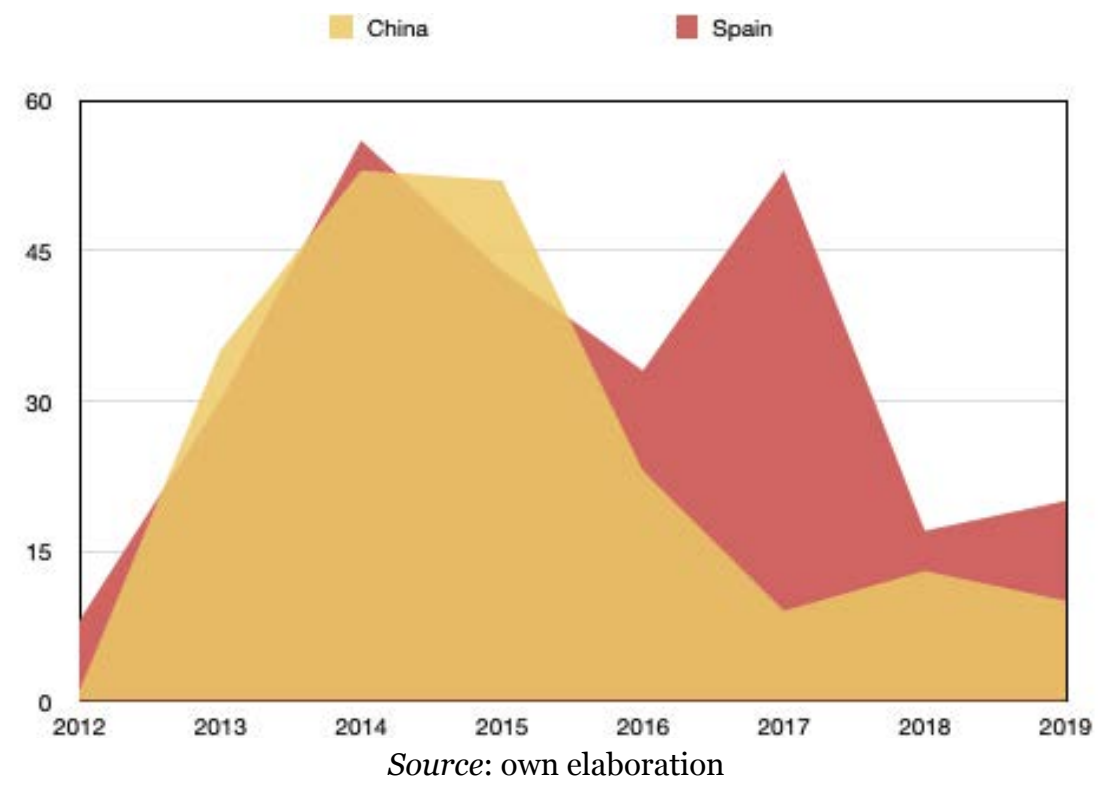


In the second phase of thematic analysis, the articles were coded by different countries, China $(n=196,41.8 \%)$ and Spain $(n=273,58.2 \%)$, using the same coding framework that includes 14 themes that have established later to identify the characteristics and presentation of the MOOCs in different countries. Ten themes out of the 14 themes mentioned in the Chinese articles $(n=196)$ differed significantly from the Spanish articles $(n=260)$.

\section{Table 3}

Themes related to the $\mathrm{MOOC}$

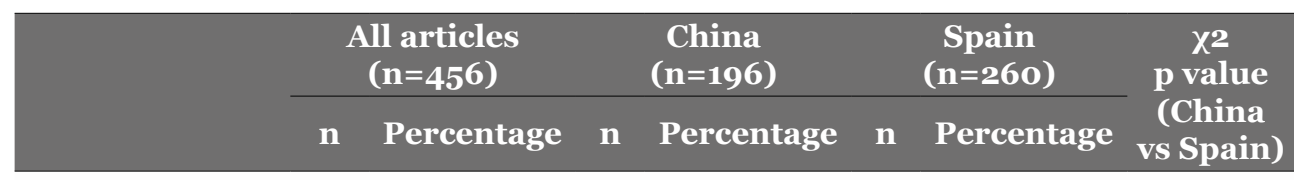

\section{Educational} aspects

\begin{tabular}{|c|c|c|c|c|c|c|c|}
\hline $\begin{array}{l}\text { 1.Universities and } \\
\text { Higher Education }\end{array}$ & 375 & 82.2 & 162 & 82.7 & 213 & 81.9 & .840 \\
\hline $\begin{array}{l}\text { 2.Primary and } \\
\text { Secondary } \\
\text { Education }\end{array}$ & 52 & 11.4 & 37 & 18.9 & 15 & 5.8 & $.000^{*}$ \\
\hline 3.Pedagogy & 346 & $75 \cdot 9$ & 164 & 83.7 & 182 & 70.0 & $.001^{*}$ \\
\hline $\begin{array}{l}\text { 4.Students and } \\
\text { learners }\end{array}$ & 310 & 68.0 & 157 & 80.1 & 153 & 58.8 & $.000^{*}$ \\
\hline 5.Teachers & 241 & 52.9 & 131 & 66.8 & 110 & 42.3 & $.000^{*}$ \\
\hline $\begin{array}{l}\text { 6.Global and } \\
\text { International } \\
\text { Education }\end{array}$ & 259 & 56.8 & 102 & 52.0 & 157 & 60.4 & .075 \\
\hline $\begin{array}{l}\text { 7.Educational } \\
\text { equity and } \\
\text { equality }\end{array}$ & 66 & 14.5 & 56 & 28.6 & 10 & 3.8 & $.000^{*}$ \\
\hline \multicolumn{8}{|l|}{$\begin{array}{l}\text { MOOC } \\
\text { Infrastructure } \\
\text { aspects }\end{array}$} \\
\hline 8.Platform & 232 & 50.9 & 132 & 67.3 & 100 & 38.5 & $.000^{*}$ \\
\hline $\begin{array}{l}\text { 9.MOOC } \\
\text { credentials and } \\
\text { certificates }\end{array}$ & 128 & 28.1 & 60 & 30.6 & 68 & 26.2 & .294 \\
\hline \multicolumn{8}{|l|}{ Social aspects } \\
\hline $\begin{array}{l}\text { 10.MOOCs and } \\
\text { enterprise }\end{array}$ & 113 & 24.8 & 22 & 11.2 & 91 & 35.0 & $.000^{*}$ \\
\hline $\begin{array}{l}\text { 11.MOOCs and } \\
\text { government }\end{array}$ & 99 & 21.7 & 66 & 33.7 & 33 & 12.7 & $.000^{*}$ \\
\hline
\end{tabular}




\begin{tabular}{|c|c|c|c|c|c|c|c|}
\hline & \multicolumn{2}{|c|}{$\begin{array}{l}\text { All articles } \\
(n=456)\end{array}$} & \multicolumn{2}{|r|}{$\begin{array}{c}\text { China } \\
(n=196)\end{array}$} & \multicolumn{2}{|r|}{$\begin{array}{c}\text { Spain } \\
(n=260)\end{array}$} & \multirow{2}{*}{$\begin{array}{c}\chi^{2} \\
\text { p value } \\
\text { (China } \\
\text { vs Spain) }\end{array}$} \\
\hline & $\mathbf{n}$ & Percentage & $\mathbf{n}$ & Percentage & $\mathbf{n}$ & Percentage & \\
\hline $\begin{array}{l}\text { 12.MOOCs and } \\
\text { employability }\end{array}$ & 99 & 21.7 & 26 & 13.3 & 73 & 28.1 & $.000^{*}$ \\
\hline $\begin{array}{l}\text { 13. Business and } \\
\text { economic }\end{array}$ & 51 & 11.2 & 21 & 10.7 & 30 & 11.5 & .782 \\
\hline \multicolumn{8}{|l|}{ Other aspects } \\
\hline $\begin{array}{l}\text { 14. The problem } \\
\text { with MOOCs }\end{array}$ & 117 & $25 \cdot 7$ & 82 & 41.8 & 35 & 13.5 & $.000^{*}$ \\
\hline
\end{tabular}

*The chi-square statistic is significant at the 0.01 level

In terms of the educational aspect, there were no statistically significant relationships between the university theme and the country focus $(p=0.840)$. Nevertheless, the relationship between the subject Primary and Secondary Education and the country category is statistically significant $(\mathrm{p}<0.000)$, and they were mentioned more times in the Chinese texts $(n=37,18.9 \%)$ than in the Spanish texts $(n=15,5.8 \%)$. The articles mentioned to education practice were significantly related to the country category, among them, Pedagogy $(\mathrm{p}<0.001)$, Teachers $(\mathrm{p}<0.000)$, Students and Learners ( $\mathrm{p}<0.000)$. In terms of educational strategies, the theme of Global and International Education was mentioned more frequently in the Spanish articles $(n=157,60.4 \%)$ than in the Chinese $(n=102,52 \%)$, but the difference was not significant $(\mathrm{p}=0.294)$. While there were more Chinese articles mentioned in the theme of Educational equality and equity $(n=56.28 .6 \%)$ than Spanish articles $(n=10$, $3.8 \%)$, and the difference is significant $(\mathrm{p}<0.000)$.

On the other hand, the relationship between non-educational aspects and country category has also been compared. There is no relationship between the MOOC infrastructure elements and the theme of MOOC credentials and certificates and the country category $(\mathrm{p}=0.294)$. However, there was a significant relationship between the theme of the MOOC platform and the country category $(p<0.000)$, where articles in the Chinese press highlighted more content on the platform $(n=132$, 67.3\%). Furthermore, the relationship between the social aspects and country category has also been compared. While MOOCs and enterprise $(n=113,24.8 \%)$ associated significantly more with one country than the other, being mentioned predominantly in articles published in Spain $(\mathrm{p}<0.000)$. MOOCs and employability were significantly related to the country category $(\mathrm{p}<0.000)$. Seventy-three Spanish articles (28.1\%) have mentioned this issue, while only 26 (13.3\%) articles in the Chinese press. The Business and economic theme was mentioned more frequently in the Spanish articles $(n=30,11.5 \%)$ than the Chinese articles $(n=21,10.7 \%)$, but in this difference, there was no significant relation $(\mathrm{p}=0.782)$. On the contrary, MOOCs and the government's issue was mentioned more in the Chinese articles than in 
the Spanish articles. The difference was significant $(\mathrm{p}<0.000)$. Finally, the issue of the MOOC problem has examined, 117 (25.7\%) articles highlighted this issue, it is significantly related to the country category $(\mathrm{p}<0,000)$, with almost half of the Chinese articles $(n=82,41.8 \%)$ frequently mentioning the problem with MOOCs, while Spanish articles mention it little ( $\mathrm{n}=35,13.5 \%)$.

After comparing the articles produced by the Chinese and Spanish press on the MOOCs, the most widely discussed themes of MOOC in both local Chinese and Spanish newspapers during the eight years also have been identified in Figure 5 (Universities and Higher Education, Students and learners, Pedagogy, Teacher, Platform, Global and International Education). However, as the total number of regular articles on MOOCs in China and Spain decreases (figure 3), all analysis themes also show a downward trend over the eight years.

\section{Figure 4}

Comparison of themes in China and Spain

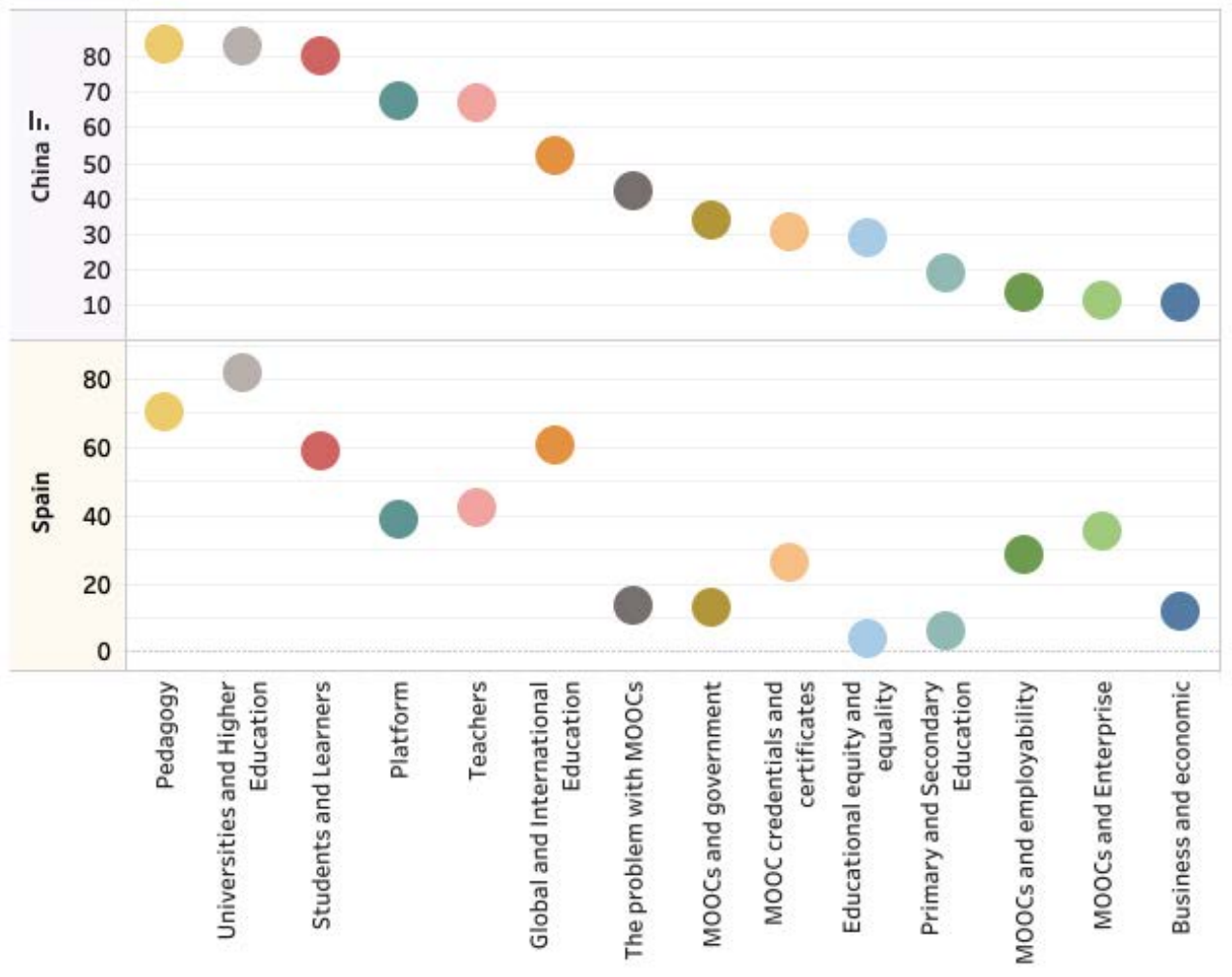

Source: own elaboration 


\section{Figure 5}

The dominant themes in Chinese and Spanish newspapers

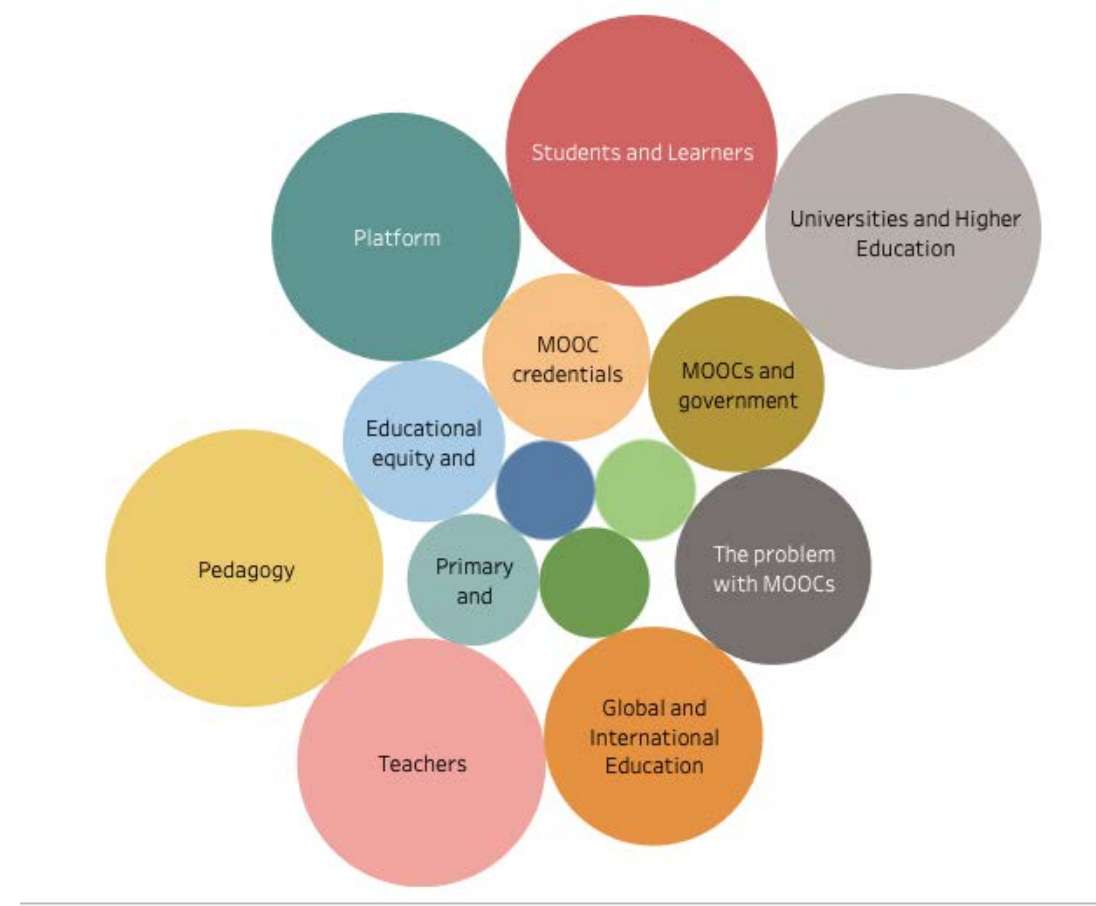

Source: own elaboration

\section{DISCUSSION AND CONCLUSION}

This study examines MOOCs' representations between China and Spain for over eight years. The quantitative content analysis contributes to the understanding that there are different representations of MOOC issues in Chinese and Spanish local newspapers. The results indicate that public opinion on the MOOC topic has changed significantly during these eight years in both countries, with 2014 being the year with the most extensive regular publication on the MOOC issue in both countries. Since then, the total number of articles shows a clear downward trend in China, and Spanish newspapers started to reduce MOOC coverage, but it increases again from 2017 onwards. The prevalence of the media discussion in both Chinese and Spanish newspapers shows that MOOCs have become an essential issue of contemporary education at the national level, whether in the western o eastern society. The social imagination about education is transformed by proliferating the Internet goes beyond the national boundaries. 
In line with the quantitative analysis, the unexpected findings suggest that economics is not an essential theme in China or Spain, which differentiates English language newspaper topics. As indicated in the previous studies, the MOOCs' finance and economic investment theme has been the dominant discourses (Bulfin et al., 2014; Kovanović et al., 2015; Dumitrica, 2017). The analysis of Chinese and Spanish news reporting brings up the possibility that MOOCs are described to improve the current education system as public goods rather than a technological and economic framework. In this consideration, the MOOCs phenomenon is not just new technological innovation. Instead, they have more profound implications in the Chinese and Spanish educational system in the long-term.

The findings also showed different media frames of the MOOCs in Chinese and Spanish languages newspapers. It seems possible that these differences are due to the different understanding of the MOOC phenomenon in China and Spain, which is indirectly influenced by existing socio-political, ideological, and cultural factors. Since most Chinese MOOC providers are universities, it is necessary to consider that the higher education institutions are mostly public and non-profit in China. Facing the challenge of a vast population, how to provide universal access to higher education and promote equity and equality in education become essential topics for Chinese education policy. Leading the world in MOOC courses and learners shows that the government has taken digital higher education as a vital strategy. The national Chinese MOOC platform provides courses not only to higher education but also primary and secondary education. On the contrary, the Spanish MOOC platform was established and promoted by universities with enterprise cooperation, specializing in providing comprehensive online learning courses for education and training. In the western educational system, getting an education is considered an individual responsibility in a society based on the neoliberal frame. Thus, MOOCs' description was articulated with the utopian vision of democratizing individuals' education through the Internet. MOOCs learners can pick their favorite courses that suit their own needs and help them better adapt to the job market.

MOOCs' media imaginary will indeed have conveyed MOOCs' understanding and their broader social meaning in different contexts. As mass media and public discourse are integral elements of educational policy, MOOC policymakers and decision-makers within government and educational institutions use mainstream media as an essential tool to get informed by MOOCs' current development (Bulfin et al., 2014). Therefore, how MOOCs are being represented in Chinese and Spanish languages newspapers should be seen as a vital element influencing digital higher education and further technological application in the online education environment. The use of language and construction of media discourse is essential not just because they reflect the social life but also constructing the social realities. The media discussions have considerable influence in sustaining and inspiring MOOCs' progression from niche educational technology to mainstream education from the general public in different countries. 
In terms of the research question of this study, some limitations and issues need further consideration. While newspaper articles present a comparison of public discourses on MOOCs in China and Spain, content analysis alone cannot determine MOOC integration into society and the extent to which public understanding correlates with media representations. The public does not consume media content passively and uncritically but is instead affected by many influences beyond the media. Exploring and comparing other media formats, such as social media, can create a more comprehensive understanding of MOOC presentations in different social life. Besides, obtaining a larger sample by including more publications can increase the findings' validity. Another possible limitation of the data used in the Mynews and China Core Newspapers Full-text Database is its text format, omitting any images included in the original articles. The research does not explicitly design the qualitative part of evaluating media discourses thoroughly and critically, considering the limited length of the text. Using a qualitative approach to compare the public discourse should be considered in the future. Besides, this study is limited to the concerns of media content produced in China and Spain. There is a clear space for further comparative research that completes MOOCs' media discussion at other national levels, such as the large higher education systems in Latin America. Particularly, it is interesting to ask the question about whose interests are the western and eastern newspapers' discourses benefit and how MOOCs' media construction is located within the social structure of power and educational systems. The portrayals of key actors and interest groups may reflect the MOOC development dynamics in the national context.

This article has sought to improve the understanding of media construction of MOOC in the Chinese and Spanish languages contexts, which were considered to have the most widely audiences and potential online learners in the world. The comparative analysis highlighted an important research area in which mainstream media may help improve understandings and transfer meanings of new educational technology to their public in different countries, and consequently helped advance scholarly understandings of the current online education environment in different cultural backgrounds.

\section{REFERENCES}

Aguado Franco, J. C. (2020). Los MOOC: ¿sustituto o complemento de la formación tradicional? Revista Tecnología, Ciencia y Educación, 16, 41-62. http://hdl.handle. net/20.500.12226/330

Benson, R. (2013). Shaping Immigration News: A French-American Comparison. University Press, Cambridge. https://doi. org/10.1017/CBO9781139034326
Brown, M., Costello, E., Donlon, E., GiollaMhichil, M., Kirwan, C., Kovanović, V., \& Hatala, M. (2016). Story of MOOCs in the Irish media: Hold the front page, 25. http://eadtu.eu/images/publicaties/ MOOCs in Europe November 2015. pdf

Bulfin, S., Pangrazio, L., \& Selwyn, N. (2014). Making "MOOCs": The construction of a 
new digital higher education within news media discourse. International Review of Research in Open and Distance Learning, 15(5), 290-305. https://doi.org/10.19173/ irrodl.v15i5.1856

Cano, V., \& Meneses, L. (2014). Los Mooc y La Educación Superior: la expansión del conocimiento. Profesorado. Revista de Currículum y Formación de Profesorado, 18(1), 3-12. https://www.redalyc.org/ pdf/567/56730662001.pdf

Comisión Europea (Ed.) (2018). Comunicación de la Comisión al Parlamento Europeo, al Consejo, al Comité Económico y Social Europeo y al Comité de las Regiones sobre el plan de acción de educación digital. https://bit. $\mathrm{ly} / 2 \mathrm{YCsVwN}$

Costello, E., Brown, M., Mhichíl, M. N. G., \& Zhang, J. (2018). Big course small talk: Twitter and MOOCs - a systematic review of research designs 2011-2017. International Journal of Educational Technology in Higher Education, 15(1), 44. https://doi.org/10.1186/s41239-0180127-9

Deimann, M. (2015). The dark side of the MOOC-A critical inquiry on their claims and realities. Current Issues in Emerging ELearning, 2(1). https://scholarworks. umb.edu/ciee/vol2/iss1/3

Dumitrica, D. (2017). Fixing higher education through technology: Canadian media coverage of massive open online courses. Learning, Media and Technology, 42(4), 454-467. https://doi.org/10.1080/17439 884.2017.1278021

García-Peñalvo, F. J., Fidalgo-Blanco, Á., \& Sein-echaluce, M. L. (2018). An adaptive hybrid MOOC model : Disrupting the MOOC concept in higher education. Telematics and Informatics, 35(4), 1018-1030. https://doi.org/10.1016/j. tele.2017.09.012

Gameel, B. G., \& Wilkins, K. G. (2019). When it comes to MOOCs, where you are from makes a difference.
Computers \& Education, 136(1), 49-6o. Elsevier Ltd. https://doi.org/10.1016/j. compedu.2019.02.014

Kovanovic, V., Joksimovic, S., Gaševic, D., Siemens, G., \& Hatala, M. (2015). What public media reveals about MOOCs: A systematic analysis of news reports. British Journal of Educational Technology, 46(3), 510-527. https://doi. org/10.1111/bjet.12277

Kovanović, V., Gašević, D., Joksimović, S., \& Siemens, G. (2016). MOOCs in the News : A European Perspective Analysis of $M O O C$ research literature, (November), 36-47. http://eadtu.eu/ images/publicaties/MOOCs in Europe November 2015.pdf

McCombs, M. E., \& Shaw, D. L. (1972). The Agenda-Setting Function of Mass Media. Public opinion Quarterly: Journal of the American Association for Public Opinion Research, 36(2), 176. https:// doi.org/10.1086/267990 https://doi. org/10.1086/267990

Medina-Salguero, R., \& Aguaded, I. (2014). Los MOOC en la plataforma educativa MiriadaX. Profesorado, 18(1), 137-153. http://hdl.handle.net/10481/31670

MOOC List. (2020). https://www.mooc-list. com/countries

Navarro, C. P. B., \& Barreto, C. T. R (2018). Los MOOC en la Educación Superior: Un Análisis Comparativo desde la oferta de Universidades Latinoamericanas. Saber, Ciencia y Libertad, 13(2), 250-260. https://doi.org/10.18041/2382-3240/ saber.2018v13n2.4639

Neuendorf, K. A. (2017). The Content Analysis Guidebook (2nd ed.). Thousand Oaks, CA: Sage.

Pappano, L. (2012). The Year of the MOOC. The New York Times, pp. 1-7. https://www.edinaschools.org/cms/lib/ MN01909547/Centricity/Domain/272/ The Year of the MOOC NY Times.pdf

Reich, J., \& Ruipérez-Valiente, J. A. (2019). The MOOC pivot. Science (New York, 
N.Y.), 363(6423), 130-131. https://doi. org/10.1126/science.aav7958

Rogers, R., Schaenen, I., Schott, C., O'Brien, K., Trigos-Carrillo, L., Starkey, K., \& Chasteen, C. C. (2005). Critical Discourse Analysis in Education: A Review of Educational Research. Review of Educational Research, 86(4), 1192-1226. https://doi. org/10.3102/0034654316628993

Shang, J., \& Cao, P. (2017). "Internet plus" and the reform of higher education: A preliminary study on the development strategy of higher education informatization in China. Peking University Education Review, 1, 173-182. http://www.oaj.pku.edu.cn/jypl/CN/ $\underline{\mathrm{Y} 2017 / \mathrm{V} 15 / \mathrm{I} 1 / 173}$

Shao, Y., Zhang, J., Costello E., \& Brown, M. (2020). Public perceptions towards MOOCs on social media: an alternative perspective to understand personal learning experiences of MOOCs. Interactive Learning Environments. https://doi.org/10.1080/10494820.2020 .1799413

Scheufele, D. A., \& Tewksbury, D. (2007). Framing, Agenda Setting, and Priming: The Evolution of Three Media Effects Models. Journal of Communication, 57, 9-20. $\quad$ https://doi.org/10.1111/j.00219916.2007.00326.x

UNESCO \& COL. (2016). Making Sense of A Guide for Policy-Makers. https:// unesdoc.unesco.org/ark:/48223/ pfooo0245122

Van Dijk, T. A. (2013). News as discourse. Routledge. https://doi. org/10.4324/9780203062784
White, S., Leon, M., \& White, S. (2015). MOOCs inside Universities: An analysis of MOOC discourse as represented in the magazines. CSEDU 2015 7th International Conference on Computer Supported Education, Proceedings, 2, 109-115. https://doi. org/10.5220/0005453201090115

Zapata-Ros, M. (2015). MOOCs, una visión crítica y una alternativa complementaria: La individualización del aprendizaje y de la ayuda pedagógica. Campus virtuales, 2(1), 20-38. http://uajournals.com/ ojs/index.php/campusvirtuales/article/ view $/ 26$

Zhang, J., Perris, K., Zheng, Q., \& Chen, L. (2015). Public response to "the MOOC movement" in China: Examining the time series of microblogging. International Review of Research in Open and Distance Learning, 16(5), 144-160. https://doi. org/10.19173/irrodl.v16i5.2244

Zhang, J., Sziegat, H., Perris, K., \& Zhou, C. (2019). More than access: MOOCs and changes in Chinese higher education. Learning, Media and Technology, 44(2), 108-123. https://doi.org/10.1080/174398 84.2019.1602541

Zheng, Y., \& Yang, R.-Y. Y. (2017). The rise of MOOCs: The literature review of research progress and hot spots of MOOCs education in mainland China. Eurasia Journal of Mathematics, Science and Technology Education, 13(9), 6165-6174. https://doi.org/10.12973/ EURASIA.2017.01056A

Zou, S. (2020). China No 1 in open courses on Internet. China daily. https:// global.chinadaily.com.cn/a/202012/14/ WS 5 fd6gfcaa31024adobagb853.html

\section{ACADEMIC AND PROFESSIONAL PROFILE OF THE AUTHOR}

Jingshan Liu. She is a Ph.D. Candidate in the Department of Communication at Universidad Carlos III de Madrid. With experience as professor in Chinese Language and Oriental Studies at Universidad Las Palmas de Gran Canaria (Spain) 
and Universidad del Desarrollo (Chile). Her main research lines are related to the development of educational technology in different social and cultural contexts. http://orcid.org/0000-0001-6088-6219

E-mail: jingshan.liu@alumnos.uc3m.es

\section{ADDRESS}

Department of Communication

Universidad Carlos III de Madrid

Calle Madrid, 135

28903 Getafe-Madrid (Spain)

Date of receipt: $31 / 12 / 2020$

Date of acceptance: 07/03/2021

Date of layout: 18/03/2021 